records, railway workers from various parts of India, and practising clinicians. All these studies revealed a significant geographical difference in the prevalence of peptic ulcer disease between the north and south of India. Peptic ulcer is uncommon in the plains of Punjab, Utter Pradesh, Rajasthan, Madya Pradesh and Gujrat, and common in Madras, Karela, Mysore, Andra Pradesh and eastern parts of India - namely, Assam, West Bengal as well as Bengladesh. It is also reported to be common in the Kashmir valley in the northern most state of India while the adjacent province of Jammu has a low incidence. These geographical differences exactly matched with the differences in dietary habits. In the low prevalence area, wheat bread (chappatti) and pulses are the staple diet and in the high incidence area boiled rice, green vegetables and highly spiced food are the staple diet. Two reasons are offered to explain the role of diet in the pathogenic of peptic ulcer namely: (1) wheat bread (chappatti) being a dry food needed a lot of chewing and excessive production of saliva, while boiled rice is sloppy and needs very little mastication and produces little saliva. These observations were confirmed and the protective role of saliva in the causation of peptic ulcer was shown," and," rice contained ulcerogenic fractions and the excessive prevalence of peptic ulcer in the rice eating areas was related to these ulcerogenic factors.

In 1972 the Indian Council of Medical Research conducted a nation wide study on the occurrence of the peptic ulcer in India. Six centres were selected, Kashmir valley, Punjab, Delhi, Madras, Goa, and Kanpur. This was a population based study and the diagnosis of peptic ulcer was based on radiological studies of the upper gastrointestinal tract and showed that the incidence of peptic ulcer in all the six areas was less than $1 \%$ and there was no significant geographical difference in the incidence of peptic ulcer between the north and the south. This study, as already mentioned, however, has some inherent problems in its design. The present endoscopic study revealed that the prevalence of peptic ulcer in Kashmir valley was $11 \%$ and the point prevalence was around $4 \%$. It also revealed that the complications of peptic ulcer were as common in Kashmir as in the west. Earlier there have been many reports showing either haemorrhage, duodenal stenosis or perforation to be common in peptic ulcer in India. We believe that most of these reports were drawn from highly selected groups of patients from the hospital records and do not represent a true incidence of complications of peptic ulcer in India.

With the advent of fibreoptic endoscopy, the diagnosis of peptic ulcer has become more accurate and to further study the geographical prevalence of peptic ulcer in Indian subcontinent we need to do similar studies in the plains of Punjab, and in south and eastern parts of India. Should geographical difference in peptic ulcer be confirmed by these studies, most likely explanation would be differences in the diet of these populations. The problem in doing such studies would be to select highly dedicated field staff and endoscopists and the acceptability of the population under study to undergo endoscopies. Public awareness of peptic ulcer occurence is important and to increase the responder rate small medical centres need to be started in these areas to treat minor ailments. The press, television and the radio need to educate the public about the importance of these studies. These methods were used in our study to gain the support and confidence of the general public, and to increase the responder rate for endoscopies.
The Indian Council of Medical Research and other national research committees in India need to look into these aspects in order to start a multicentric endoscopic study on the prevalence of peptic ulcer in India. It will go a long way to finally solve the question of geographical distribution of peptic ulcer in the Indian subcontinent, and will formally establish the role of dietary factors in the cause of peptic ulcer.

MS KHUROO SHER-I-KASHMIR Institute of Medical Sciences, Srinagar 1900ll.

1 Khuroo MS, Mahajan R, Zargar SA et al. Prevalence of peptic ulcer in India: An endoscopic and epidemiological study in urban Kashmir. (in 1989; 30:930-934.

2 Dogra JR. Studies on peptic ulcer in South India IV. Incidence of peptic ulcer in India with particular reference to South India. Indion fournal of Medical Research 1941; 29: 665-676.

3 Malhotra SI. Peptic Ulcer in India and it aetiology. (iut 1964; 5: +12-416

+ Sehgal AK, Chhuttani PN, Gupta BR, Malik K and Gupta HD. Epidemiology of peptic ulcer in an urban community in Chandigarh. Indian foumal urban community in Chandigarh. Indian

5 Malhotra SI, Saigal ON, and Mody GD. Role of saliva in the aetiology of peptic ulcer. British Medical fournal 1965; 1: 1220-1222.

6 Malhotra SL.. Protective action of saliva in peptic ulceration. Studies on the effect of saliva on gastric secretion with dve-dilution technique. Scandinazian foumal of (Fastroenterology 1967;2: 95-104.

7 Jayarai AP, Tovey FI, Clark CG et al. The ulcerogenic and protective action of rice and rice fractions in experimental peptic ulceration. C.lin Science 1987; 72: $463-466$.

\section{Short bowel syndrome and somatostatin 201-} 995

SIR, - I was interested to read the paper from S Jarnum's group (Gut 1989; 30: 943-9), suggesting that in patients with severe short bowel syndrome, the somatostatin analogue SMS 201-995 could increase net absorption of water sodium after reduced secretion of digestive juices rather than by increasing absorptive capacity. The authors did mention our study of a patient with pancreatic cholera (vipoma) in whom the continuous intravenous infusion of $8 \mu \mathrm{g} / \mathrm{kg} / \mathrm{h}$ cyclic somatostatin 14 had a dramatic effect on diarrhoea. They did not, however, quote the perfusion study of water and electrolyte movements we performed in the smal bowel of this patient and of healthy contro subjects. We found that in controls the decrease in intraluminal water and sodium flow rate within the distal ileum seen during somatostatin infusion was mostly accounted for by the sharply reduced entry of water and electrolytes from the duodenum into the jejunum. This finding agrees with the author's hypothesis on the mechanism of action of SMS 201-995 in the short bowel syndrome. In the patient with vipoma, however, not only the entry of water and sodium into the jejunum was reduced, but also the jejunal fluid secretion was markedly decreased, in parallel with the return to normal values of circulating vasoactive intestinal peptide. Thus, exptrapolation of pharmacological findings in normal subjects to patients with various causes of diarrhoea should be cautious.

$$
\begin{array}{r}
\text { J C RAMBAUD } \\
\text { Service de Gastroenterologie, } \\
\text { Hopital Saint-Lazare, } \\
\text { Paris, 75010, France }
\end{array}
$$

1 Ruskoné A, René E, Chayvialle JA, et al. Effect of somatostatin on diarrhea and on small intestinal water and electrolvte transport in a patient with pancreatic cholera. Dig Dis Sci 1982; 27: 459-66.

\section{Reply}

SIR, - We thank Professor Rambaud for his comments on our paper.' Professor Rambaud's group has found, that somatostatin infusion in normal subjects decreases small intestinal flow to the distal ileum, mainly by reducing water and electrolvte entry from the duodenum to the jejunum. In contrast, a patient with vipoma showed decreased jejunal secretion as well. They conclude, that extrapolation of pharmacological findings in normal subjects to patients with various causes of diarrhoea should be made cautiously, a conclusion to which we fully agree.

Five of the six patients we studied had inactive Crohn's disease. It has been shown, that the relative frequency of various endocrine cells and the distribution and frequency of peptide containing nerve fibres in the gut do not differ between patients with Crohn's disease and controls.' Patients with small bowel resection have shown increased release of several gut hormones after a test meal. ${ }^{+} \mathrm{At}$ present it is, however, difficult to ascertain the integrated effect of the altered hormone response on gastrointestinal secretions. We found that the reduction of stomal output during supply of SMS 201-995 in a patient with only $40 \mathrm{~cm}$ jejunum left was equal to the reduction in patients with longer small intestinal remnant. It is therefore possible, although not investigated in our study, that the main effect of SMS 201-995 in our patients, like in Professor Rambaud's normal subjects, was a reduction of gastroduodenal and pancreaticobiliary secretions rather than a reduction in jejunal secretions.

$$
\begin{array}{r}
\text { KARIN LADEFOGED) } \\
\text { KNUDCCHRISTENSEN } \\
\text { Medical Dept P', } \\
\text { Rigshospitalet, } \\
\text { DK-2100 Copenhagen, }
\end{array}
$$
Denmark

1 Ladefoged K, Christensen KC, Hegnhoi J, Jarnum $\mathrm{S}$. Effect of a long acting somatostatin analogue SMS 201-995 on jejunostomy effluents in patients with severe short bowel syndrome. (iut 1989; 30: 943-9.

2 Ruskoné A, René E, Chayvialle JA, et al. Effect of somatostatin on diarrhea and on small intestina water and electrolvte transport in a patient with pancreatic cholera. Dig Dis Si 1982; 27: 459-66.

3 Sjölund $\mathrm{K}$, Schaffalitzky de Muckadell OB Fahrenkrug $J$, Häkanson $R$, Peter:en $B G$; Sundler $F$. Peptide-containing nerve fibres in the gut wall in Crohn's disease. ( iut 1983; 24: 724 33 .

+ Besterman HS, Adrian TE, Mallinson CN, $t$ t al. (jut hormone release after intestinal resection. (iut 1982; 23: 85+61.

Pancreatic Inflammatory Disease Cell Biological Concepts and Therapeutic Applications

An international workshop will be held in Marburg, West Germany on 26 and 27 April, 1990. For further information please contac Prof Dr G Adler, Zentrum Für Innere Medizin, Baldinger Str, D-3550 Marburg/L Federal Republic of Germany. 